\title{
Influence of Chute Exit Velocity and Fescue Toxicosis on Steer Grazing and Finishing Growth, Immune Responses, and Carcass Characteristics
}

\author{
AW Altman ${ }^{1}$, MB Kudupoje ${ }^{2}$, AA Adams ${ }^{3}$, KR McLeod $^{1}$ and ES Vanzant ${ }^{1, *}$ \\ ${ }^{1}$ Department of Animal Science, University of Kentucky, Lexington, KY, USA \\ ${ }^{2}$ Alltech Inc, Nicholasville, KY, USA \\ ${ }^{3}$ Department of Veterinary Science, University of Kentucky, Lexington, KY, USA
}

*Corresponding author: ES Vanzant, Department of Animal Science, University of Kentucky, Lexington, KY, USA, E-mail: evanzant@uky.edu

Received: 03 Sep, 2020 | Accepted: 23 Sep, 2020 | Published: 28 Sep, 2020

Citation: Altman AW, Kudupoje MB, Adams AA, McLeod KR, Vanzant ES (2020) Influence of Chute Exit Velocity and Fescue Toxicosis on Steer Grazing and Finishing Growth, Immune Responses, and Carcass Characteristics. J Anim Sci Res 4(3): dx.doi.org/10.16966/2576-6457.146

Copyright: (C) 2020 Altman AW, et al. This is an open-access article distributed under the terms of the Creative Commons Attribution License, which permits unrestricted use, distribution, and reproduction in any medium, provided the original author and source are credited.

\section{Abstract}

Mixed breed steers ( $n=120)$ from 3 sources were weighed and evaluated for exit velocity. Steers were assigned an exit velocity treatment (high/low; based on relative ranking in measured exit velocities within source), and assigned to either toxic endophyte or novel endophyte tall fescue pastures ( $n=20$ pastures; 6 animals/pasture) blocked by source with equal representation of exit velocity treatments in each pasture. Pasture groups were randomly assigned to a control or glucomannan supplement. Following grazing, steers were transitioned to drylot pens ( $n=40$ pens) for finishing after $110 \mathrm{~d}$ on pasture and harvested at approximately $681 \mathrm{~kg}$. Drylot pen assignment was established by placing steers of the same exit velocity treatment within each pasture in the same pen, and steers were fed a corn-based finishing diet. Blood was collected on d110, 124, and 138 for evaluation of peripheral lymphocyte interferon- $\gamma$ production, with additional blood collected on d138 to measure Leptospirosis pomona titer response. Supplementation did not affect responses $(P>0.10)$. Finishing and carcass data were analyzed as a $2 \times 2$ factorial (endophyte and exit velocity treatments). Steers on toxic endophyte pasture had lower grazing average daily gain $(P<0.01)$ and higher finishing average daily gain $(P=0.07)$ and gain:feed ratios $(P<0.01)$. Low exit velocity steers consumed more dry matter $(P=0.06)$ but had lower gain: feed ratios $(P=0.01)$ over the finishing period. Steers grazing toxic endophyte fescue had higher titer responses to Leptospirosis pomona $(P=0.09)$, but peripheral lymphocyte interferon- $\gamma$ production was not different $(P \geq 0.25)$ between endophyte or exit velocity treatments. Analysis of carcass data detected higher kidney, pelvic, and heart fat for toxic endophyte steers $(P=0.05)$, and low exit velocity steers had higher final yield grades $(P=0.10)$. No other carcass differences were detected. These data indicate previous exposure to toxic endophyte tall fescue may lead to compensatory growth during finishing and that effects of exit velocity on intake, efficiency, and growth may be more complex than previously recognized.

Keywords: Endophyte; Steer; Exit velocity; Lymphocyte; Vaccination

\section{Introduction}

Exit velocity has been considered one of the most practical and objective measures of temperament in cattle [1]. This behavioral measure has been found to be related to both immunological function $[2,3]$ and feedlot growth performance [4-6]. However, less is known about relationships between exit velocity and performance during grazing [1], especially with pastures containing toxic fescue.

Cattle grazed on toxic endophyte (Epichloë coenophiala)-infected tall fescue pastures experience a syndrome known as fescue toxicosis. Animals suffering from this syndrome can exhibit several symptoms including decreased feed intake and average daily gain (ADG), elevated respiration rate and body temperature, rough hair coat, and loss of circulation to extremities $[7,8]$. However, prior exposure to tall fescue pastures has been reported to improve $[9,10]$ or have no effect [11] upon subsequent feedlot growth performance, whereas research examining feedlot cell-mediated and humoral immunity during post-fescue grazing periods is limited, especially when considering potential modulating effects related to temperament measures like exit velocity.

Therefore, the objective of this experiment was to evaluate the relationship of exit velocity with growth and immune function during and following a period of grazing either toxic endophyte or non-toxic tall fescue.

\section{Materials and Methods}

All methods were approved by the University of Kentucky Institutional Animal Care and Use Committee.

\section{Animal background}

Mixed-breed beef steers ( $\mathrm{n}=120$; BW $=304 \pm 33 \mathrm{~kg}$ ) were purchased by order buyer from three sources. Upon arrival at the University of Kentucky's Oran C. Little Research Unit, cattle were weighed and 
evaluated for exit velocity using previously published methods [12]. Prior to the beginning of the grazing period, steers were backgrounded for 28 days on grass hay and mineral supplement. During this time, bacterial and viral vaccinations (Bovi-Shield Gold ${ }^{\circ}$, Zoetis, Florham Park, NJ; Once $\mathrm{PMH}^{\circledR}$, Merck Animal Health, Summit, NJ; Somubac ${ }^{\oplus}$, Zoetis; Ultrachoice ${ }^{\circ}$, Zoetis; Autogenous Pinkeye, Central KY Vet Center), and an injection of anthelmintic (Dectomax ${ }^{\oplus}$, Zoetis), were administered. The 120 animals used in this experiment were selected from a group of 136 head that were backgrounded. Animals were excluded from this study for existing health problems (respiratory disease, $n=2$; eye scars from previous pinkeye infections, $n=2$; minor physical injury, $n=3$ ) and to improve the uniformity of animal weights $(n=6)$ and exit velocity measurements $(n=3)$ in the experimental group.

\section{Treatment assignment}

Treatments were arranged in a $2 \times 2 \times 2$ factorial arrangement in a split plot design with two whole-plot factors and one sub-plot factor. Whole plot factors included fescue/endophyte association (non-toxic $v s$. toxic; E- and $\mathrm{E}+$, respectively) and supplement type (control vs. glucomannan-containing low moisture mineral block) and were assigned to pasture groups ( $\mathrm{n}=6$ steers/pasture). Supplements were identical in composition (Table 1), with the glucomannan supplement additionally including a proprietary additive to provide $6 \mathrm{~g} \cdot \mathrm{hd}^{-1} \cdot \mathrm{d}^{-1}$ glucomannan. Access to blocks was controlled to target daily consumption of $230 \mathrm{~g} \cdot \mathrm{hd}^{-1} \cdot \mathrm{d}^{-1}$. The subplot factor (experimental unit=individual animals) was exit velocity, which was assigned using the measurements obtained from steers upon arrival at the research unit. Source groups were stratified by exit velocities and split into two equal halves to form high and low exit velocity (EV) treatment groups. These exit velocity treatment designations were used to balance pastures for potential temperament effects so that each pasture had 3 low EV steers and 3 high EV steers. There were no main effects or interactions involving supplement type for any response variable $(\mathrm{P}>0.10)$. Thus, supplement type was removed from the statistical model for all results, such that the final model was a split plot design without the originally modeled $2 \times 2$ factorial arrangement in the whole plot.

Cattle were assigned to either novel, nontoxic endophyte [13] (Lacefield MaxQ II) or toxic endophyte pastures. Animal groups were balanced for body weight, blocked by source, randomly assigned to pastures, and grazed for 110 days. Pastures used in this study were

Table 1: Composition of supplements ${ }^{\mathrm{a}}$ provided to steers during $110 \mathrm{~d}$ grazing period.

\begin{tabular}{|l|c|}
\hline \multicolumn{1}{|c|}{ Ingredient } & Inclusion Rate \\
\hline Salt & $85.00 \%$ \\
\hline Magnesium & $4.00 \%$ \\
\hline Copper & $2000 \mathrm{ppm}$ \\
\hline Selenium & $50 \mathrm{ppm}$ \\
\hline Zinc & $4000 \mathrm{ppm}$ \\
\hline Manganese & $7500 \mathrm{ppm}$ \\
\hline lodine & $125 \mathrm{ppm}$ \\
\hline Cobalt & $15 \mathrm{ppm}$ \\
\hline Vitamin A & $200,000 \mathrm{IU} / \mathrm{lb}$ \\
\hline
\end{tabular}

a'Glucomannan treatment supplement contained $30 \mathrm{~g} / \mathrm{kg}$ proprietary glucomannan additive.
1.52 hectares in area. Supplement treatments were randomly assigned within pasture pairs. Stocking density was set at $1200 \mathrm{~kg}$ initial BW/ hectare (6 animals/pasture), a moderate to low stocking rate for this location [14].

Following the grazing period, steers were moved to a dry lot and housed in $2.4 \times 14.6 \mathrm{~m}$ pens, with 3 animals per pen. Steers were placed in pens, grouped by exit velocity designation from the same grazing pasture, and remained until completion of the finishing period $(167 \mathrm{~d})$, at which point they were removed for slaughter. Thus, the experimental unit was pen (3 steers), which maintained the integrity of the design structure from the grazing phase. Data from the receiving period were a focal point in this study, as we hypothesized prior exposure to E+ fescue may exacerbate potential changes in cellmediated immunity associated with the sudden change in environment and diet. Steers were started on a typical receiving ration (Table 2) and transitioned to a finishing diet over the $28 \mathrm{~d}$ receiving period. Due to decreased consumption during the first week, steers remained on the initial diet for 2 weeks. Following this two-week period, dietary energy concentrations were increased weekly over the next three weeks by decreasing the proportion of corn silage while increasing proportions of cracked corn and distiller's dried grains. Feed bunks were checked once daily and managed to ensure steers had ad libitum access to rations, which were prepared each morning.

\section{Pasture ergopeptide analysis}

One week prior to the grazing period, 5 subsamples per pasture were collected using an $\mathrm{X}$ pattern across each pasture, with sampling sites chosen at random and subsamples combined to form one pasture sample. After collection, samples were frozen at $-20^{\circ} \mathrm{C}$, freeze dried (Botanique Model 18DX48SA freeze drier, Botanique Preservation Co., Peoria, AZ), ground through a 1-mm screen on a Wiley Mill Model 4 (Thomas Scientific, Swedesboro, NJ) and analyzed using a high-performance liquid chromatograph with a florescence detector to quantify ergovaline and ergovalinine concentrations, as developed by Yates SG, et al. [15] and modified as in Aiken GE, et al. [16]. Ergovaline and ergovalinine were identified by excitation at $310 \mathrm{~nm}$ and detection at $420 \mathrm{~nm}$. Samples were specifically analyzed for ergovaline and its isomer, ergovalinine, as ergovaline has been implicated as a primary causative agent of fescue toxicosis [17] and isomerization is known to occur during extraction and analysis $[15,18,19]$.

\section{Body weight measurement}

Body weight was measured at approximate 4-week intervals throughout the grazing season (d0, 32, 61, 89, 110), 14-day intervals

Table 2: Diet composition of $167 \mathrm{~d}$ finishing period (post-grazing).

\begin{tabular}{|c|c|c|c|c|}
\hline & \multicolumn{4}{|c|}{ \% of DM } \\
\hline & Weeks 1-2 & Week 3 & Week 4 & Weeks 5-24 \\
\hline Corn Silage & 70 & 50 & 35 & 10 \\
\hline $\begin{array}{l}\text { Distiller's Dried } \\
\text { Grains }\end{array}$ & 10 & 20 & 25 & 25 \\
\hline Cracked Corn & 10 & 20 & 30 & 27.5 \\
\hline High Moisture Corn & 0 & 0 & 0 & 27.5 \\
\hline Supplement ${ }^{\mathrm{a}}$ & 10 & 10 & 10 & 10 \\
\hline
\end{tabular}

aSupplement contained macro and trace minerals and vitamins formulated to support ADG of $1.93 \mathrm{~kg} / \mathrm{d}$, along with urea, monensin, and tylosin, in a ground corn carrier. 
during the first $28 \mathrm{~d}$ of the finishing period (d 110, 124, and 138), and on approximately $28 \mathrm{~d}$ intervals throughout the rest of the finishing period (d166, 194, 235, 256, 277). Potential error associated with gut fill differences was diminished during the grazing season by removing steers from pasture the night before each weigh day and placing them in dry lot pens without access to feed or water for approximately 16 hours prior to weighing. During the receiving and finishing periods, steers did not receive daily rations until after body weight had been collected, although access to water was not restricted during these periods. Steers were finished to an average body weight of $680 \mathrm{~kg}$. Due to differences in growth rates, and to ensure all carcasses were similar in size, steers were harvested in 3 groups balanced across treatments over a 7-week period.

\section{Carcass measurements}

Cattle were weighed before feeding on the final day of the feeding period (which varied among groups as described above) and transported approximately $770 \mathrm{~km}$ to a commercial slaughter facility (Tyson Fresh Meats, Joslin, IL). Average shrink was determined by dividing group weights obtained at the slaughter plant by the sum of live animal weights obtained before loading. Hot carcass weights were divided by individual live weights, adjusted for average shrink, to determine dressing percent. Ribeye area, marbling, backfat thickness and percentage kidney, pelvic, and heart fat $(\mathrm{KPH})$ were determined using the USDA camera system with Video Image Analysis and provided by Tyson. Yield grade was calculated as $2.5+(0.984 \times$ backfat, $\mathrm{cm})+(0.2 \times \mathrm{KPH}, \%)+(0.0084 \times \mathrm{HCW}, \mathrm{kg})-\left(0.0497 \times \mathrm{LM}\right.$ area, $\left.\mathrm{cm}^{2}\right)$ [20].

\section{Blood collection and analysis}

Blood was collected via jugular venipuncture for all analyses of blood parameters. During the grazing period, $10 \mathrm{~mL}$ serum samples were collected from each steer into spray-coated silica Vacutainer ${ }^{\circ}$ tubes (Becton Dickinson, Franklin Lakes, NJ) on d32 and d110 for prolactin analysis, which was conducted by the Schrick laboratory at the University of Tennessee. Serum samples were also collected utilizing the same methodology on $\mathrm{d} 110$ and $\mathrm{d} 138$ ( $\mathrm{d} 0$ and $\mathrm{d} 28$ of the finishing period) to evaluate baseline and titer responses against an administered Leptospirosis pomona vaccine (L5 SQ, Merck).

In addition, during the receiving period, samples were collected from a subset of high exit velocity steers $(n=20 ; 1$ from each pasture) on days 0,14 , and 28 , to evaluate lymphocyte interferon-gamma (IFN- $\gamma$ ) production. Because the number of samples that could be simultaneously processed was limited, blood samples for lymphocyte analysis were restricted to only high exit velocity animals, in an effort to delineate effects due to supplement type, none of which were ultimately significant. Although our subsetting strategy greatly reduced the likelihood of detecting potential exit velocity effects, these effects were evaluated within the tested subgroup by using exit velocity as a continuous, rather than categorical, variable.

\section{PBMC isolation and stimulation}

Peripheral blood mononuclear cells (PBMC) were isolated and stimulated from the heparinized whole blood samples using a modified protocol adapted from the methods of Breathnach CC, et al. [21]. Briefly, the three tubes collected from each sample were combined in $1-50 \mathrm{~mL}$ centrifuge tube and spun at $800 \mathrm{x}$ g for 30 minutes using a slow brake, with the resulting buffy coat transferred to a new tube and rinsed with $10 \mathrm{~mL}$ of warm PBS. This cell solution was layered over $10 \mathrm{~mL}$ Ficoll-PaquePlus ${ }^{\mathrm{Tm}}$ solution (Amersham Biosciences, Piscataway, NJ), and spun at $500 \mathrm{xg}$ for 30 minutes using a slow brake.
Cells were harvested, placed in a new tube containing $20 \mathrm{~mL}$ PBS, and centrifuged at $500 \mathrm{x}$ g for 10 minutes using a fast brake. Cells were resuspended in $5 \mathrm{~mL}$ PBS, and to this suspension $10 \mathrm{~mL} \mathrm{D2O}$ and 10 $\mathrm{mL}$ RPMI were added, with tubes topped off with PBS to achieve a final volume of $45 \mathrm{~mL}$. These tubes were centrifuged at $300 \mathrm{x}$ g for 10 minutes using a fast brake, and all subsequent spins were performed using these specifications. Supernatant was dumped from tubes, and tubes were again topped off to $45 \mathrm{~mL}$ using PBS to resuspend and wash cells. Tubes were centrifuged, supernatant dumped, and $10 \mathrm{~mL}$ of PBS was used to resuspended cells. A subsample of $100 \mu \mathrm{L}$ was obtained from each sample and mixed with $900 \mu \mathrm{L}$ of PBS for quantifying PBMC concentration in each sample using a Vicell Counter-XR (Beckman Coulter, Miami, FL) for use in determining the volume necessary for plating samples in duplicate at $1 \times 10^{6}$ cells $/ \mathrm{mL}$. The appropriate volume from each tube was transferred to a $15 \mathrm{~mL}$ tube and centrifuged. Resulting supernatant was dumped from each tube, and cells were resuspended with $4 \mathrm{~mL}$ cRPMI ( $10 \%$ fetal bovine serum, $1 \%$ penicillin-streptomycin-glutamine, $0.1 \% 2$-mercaptoethanol, and $88.9 \%$ RPMI). Cells were plated in 2 wells of a 24 well plate at $1 \times 10^{6}$ cells $/ \mathrm{mL}$.

Samples were arranged on a 24 well plate so that duplicate samples were adjacent to each other in the same row, which served as control and stimulated samples. All wells were supplemented with $2 \mu \mathrm{L}$ of brefeldin A (BFA), and $10 \mu \mathrm{L}$ of phorbol 12-myristate 13-acetate (PMA)/ionomycin was added only to stimulated sample wells. Sample plates were placed in an $5 \% \mathrm{CO}_{2}$ incubator for 4 hours at $37^{\circ} \mathrm{C} .200$ $\mu \mathrm{L}$ was removed from each incubated well, transferred to a 96 well plate, and spun at $500 \mathrm{x}$ g for 5 minutes, with resulting supernatant dumped. $100 \mu \mathrm{L}$ of $2 \%$ paraformaldehyde was added to each well, and plates were wrapped in aluminum foil and placed in a $4^{\circ} \mathrm{C}$ refrigerator overnight.

\section{Intracellular staining and flow cytometry}

Staining of PBMCs for IFN- $\gamma$ and flow cytometer protocols were as described by Breathnach CC, et al. [21]. Briefly, the morning after cells were fixed in paraformaldehyde, plates were centrifuged at $500 \mathrm{x}$ g for 5 minutes and supernatant dumped. Cells were rinsed with $150 \mu \mathrm{L}$ saponin buffer ( $1 \%$ fetal bovine serum, $0.1 \%$ saponin, and $0.1 \%$ sodium azide), and plate was centrifuged at $500 \mathrm{x}$ g for 5 minutes, with resulting supernatant dumped. Intracellular staining was performed by reconstituting mouse IgG1 anti-bovine IFNgamma FITC conjugated antibody in saponin buffer using a $10 \mu \mathrm{g} / \mathrm{mL}$ formulation. After addition of the antibody, plates were incubated on ice for 30 minutes. Plates were centrifuged at $500 \mathrm{x}$ g for 5 minutes and saponin buffer was used to resuspend PBMCs. Plates were centrifuged, supernatant dumped, and each well received $200 \mu \mathrm{L}$ FACS buffer. An Attune NxT flow cytometer (Thermo Fisher Scientific, Waltham, MA) was used to identify and analyze the lymphocyte population subset of isolated PBMCs, with forward and side scatter parameters limited to 30,000 gated events. Stimulated samples were compared to control samples, which were gated at $1 \%$, for determination of the proportion lymphocytes producing IFN- $\gamma$ and the average production of IFN- $\gamma$ by the lymphocyte population. These two parameters were multiplied together to approximate the total IFN- $\gamma$ produced by the analyzed lymphocyte population [22].

\section{Prolactin analysis}

Plasma samples collected on $\mathrm{d} 32$ and $\mathrm{d} 110$ of the grazing period were analyzed for prolactin concentrations by radioimmunoassay [23] in the Schrick laboratory at the University of Tennessee. The intra- and inter-assay CVs for samples were $7.73 \%$ and $3.23 \%$, respectively. 


\section{Leptospirosis pomona}

Serum blood samples were subjected to a microscopic agglutination test for detection of Leptospirosis pomona antibodies [24]. Animals without seronegative baseline titers on $\mathrm{d} 110$ were excluded from further humoral response analyses $(n=12)$.

\section{Fescue tolerance genetic SNP analysis}

On d110, whole blood from each animal was applied to individual sample cards and sent to AgBotanica, LLC (Columbia, MO) for T-Snip ${ }^{\text {tu }}$ score analysis, which is a proprietary test purported to be a predictor of animals' growth performance when grazed on endophyte-infected pastures. T-Snip ${ }^{\text {Tw }}$ analyzes bovine DNA to determine tolerance to endophyte-infected tall fescue based on multiple genetic markers. Higher score values are associated with higher fescue tolerance.

\section{Receiving and finishing dry matter intake}

Dry matter intake was determined on a per-pen basis by subtracting the weekly dry matter weight of refused feed from the total dry matter offered for the week. Ration ingredients were sampled weekly, and refused feed was pooled within block and subsampled in triplicate each week into previously weighed trays, weighed, and placed in a forced-air drying oven at $55^{\circ} \mathrm{C}$ for 24 hours for DM determination.

\section{Statistical analysis}

Data collected during the grazing period were analyzed as a split plot with endophyte pasture type $(\mathrm{E}-/ \mathrm{E}+)$ as the whole plot treatment and exit velocity (high/low) as the subplot treatment. When a RCBD whole plot structure was used with the split plot design, variance estimates for the subplot (residual) error for most of the ADG responses were not different from zero, resulting in non-positive definite covariance matrix estimates. Ultimately, the issues stemmed from the fact that the blocking factor accounted for a trivial portion of the variance. Thus, block was removed from the whole plot in these instances. Data were analyzed using the mixed procedure of SAS (9.4, Cary, N.C.). The Kenward-Roger method was used to calculate the denominator degrees of freedom, and block was included as a random effect. Response variables investigated included average daily gain (interval and whole period; $\mathrm{ADG}$ ) and prolactin concentrations.

Receiving and finishing period data were also analyzed as a randomized complete block design using the mixed procedure of SAS, with the denominator degrees of freedom calculated using the Kenward-Roger method. Unlike with the grazing period, there was no sub-plot for these two periods as pens comprised the experimental unit for all treatment factors. Main effects were endophyte pasture type (E+/E-) and exit velocity (high/low). Response variables for both periods included ADG, dry matter intake (DMI), and gain to feed ratio (G:F), with two steers removed from analyses of these variables due to poor growth (consistent outlier across first 3 weigh periods; $\mathrm{n}=1$ ) and morbidity (death due to anaplasmosis; $\mathrm{n}=1$ ). There were no indications of health problems for these animals during either the backgrounding or grazing phases of the study. The receiving period additionally included Leptospirosis pomona titer responses and measures of lymphocyte proportions and production of IFN- $\gamma$. Antibody titer data were analyzed as described for ADG, DMI, and G:F. The lymphocyte data included observations for a total of 20 steers (as previously described) and exit velocity was incorporated as a covariate rather than a treatment.

Carcass data were analyzed as a randomized complete block design using the mixed procedure of SAS, and the Kenward-Roger denominator degrees of freedom method. Response variables included hot carcass weight, dressing percentage, marbling score, yield grade, backfat thickness, kidney pelvic heart fat percentage, and ribeye area. Due to differences in growth rates between the blocks, three shipment dates were required to ensure all animals were finished at slaughter. Due to slower growing animals within the first three blocks, 4 animals from these blocks were excluded from analysis as they were $143.6 \mathrm{~kg}$ $( \pm 7.98)$ below the targeted $680 \mathrm{~kg}$ finished weight by day of shipment for their respective blocks.

Significance for all response variables across all periods was set at $\mathrm{P}<0.10$, and trends at $0.10<\mathrm{P}<0.15$.

\section{Results}

\section{Grazing period}

Pasture data and prolactin responses: Total ergovaline + ergovalinine concentrations are presented in Table 3. E+ pastures contained higher concentrations of these two isomers than E- pastures $(\mathrm{P}<0.01)$ and ergotamine (evidence of Claviceps infection that could potentially confound attribution of ergovaline effects) was not detected in any sample.

Prolactin concentrations were over 3-fold greater for E- steers on d32 and d110 $(\mathrm{P}<0.01$; Table 4$)$. Exit velocity did not affect prolactin concentrations $(\mathrm{P}>0.12)$. On $\mathrm{d} 32$, high exit velocity steers tended to have lower plasma concentrations $(\mathrm{P}=0.12)$, but this trend was not evident on $\mathrm{d} 110(\mathrm{P}=1.00)$, and interactions with endophyte status were not present $(\mathrm{P}>0.41)$.

Average daily gain: The effects of endophyte, exit velocity, and their interaction on ADG are presented in Table 5. For the overall grazing period, E- steers experienced greater ADG compared to E+ steers $(\mathrm{P}<0.01 ; 0.58$ vs $0.45 \pm 0.054 \mathrm{~kg} / \mathrm{d})$. Animals designated as low exit velocity tended to have greater ADG across the entire grazing period $(\mathrm{P}=0.14 ; 0.54$ vs. $0.49 \pm 0.056 \mathrm{~kg} / \mathrm{d}$, respectively), with no interactions between endophyte and exit velocity treatments detected for this period $(\mathrm{P}=0.68)$.

To evaluate one commercially available test aimed at identifying genetic differences in toxic endophyte tolerance, T-Snip ${ }^{\text {th }}$ values were evaluated as a covariate in analyses for ADG responses. These values proved to be ineffective in explaining any growth-related response differences due to endophyte, and no correlation was observed

Table 3: Presence of ergovaline, ergotamine, and related isomers in toxic endophyte $(E+)$ and novel endophyte $(E-)$ pastures.

\begin{tabular}{|l|c|c|c|c|}
\hline & \multicolumn{2}{|c|}{ Endophyte Treatment } & & P-Value \\
\hline & E- & E+ & SEM & Endo \\
\hline Ergovaline + Ergovalinine $^{\text {a }}$ & 43 & 425 & 38.2 & $<0.01$ \\
\hline Ergotamine + Ergotaminine $^{\text {a }}$ & 0 & 0 & 0 & - \\
\hline
\end{tabular}

${ }^{a}$ Values represent the sum of isomers, in ppb.

Table 4: Influence of toxic ( $E+$ ) and novel (E-) endophyte tall fescue and exit velocity $(E V)$ on serum prolactin concentration in steers $(n=120)$ during $110 \mathrm{~d}$ grazing period.

\begin{tabular}{|l|c|c|c|c|c|c|c|c|}
\hline & \multicolumn{2}{|c|}{ E- } & \multicolumn{2}{c|}{ E+ } & \multicolumn{3}{c|}{ P-Value } \\
\hline & Low & High & Low & High & SEM & Endo * EV & Endo & EV \\
\hline Day 32 & 4.44 & 4.57 & 3.41 & 3.06 & 0.171 & 0.49 & $<0.001$ & 0.12 \\
\hline Day 110 & 3.82 & 3.93 & 2.82 & 2.71 & 0.150 & 0.41 & $<0.001$ & 1.00 \\
\hline
\end{tabular}

${ }^{a}$ Means are presented as natural log-transformed, original units in $\mathrm{ng} / \mathrm{mL}$. 
Table 5: Influence of toxic $(E+)$ and novel (E-) endophyte tall fescue and exit velocity $(E V)$ on steer $(n=120)$ daily gains during a $110 d$ grazing period.

\begin{tabular}{|l|c|c|c|c|c|c|c|c|}
\hline & \multicolumn{2}{|c|}{ E- } & \multicolumn{2}{c|}{ E+ } & \multicolumn{3}{c|}{ P-Values } \\
\hline & Low & High & Low & High & SEM & Endo * EV & Endo & EV \\
\hline d0 to 32 & 0.29 & 0.24 & 0.13 & 0.06 & 0.103 & 0.87 & 0.13 & 0.24 \\
\hline d32 to 60 & 0.85 & 0.82 & 0.76 & 0.72 & 0.100 & 0.97 & 0.21 & 0.44 \\
\hline d60 to 89 & 0.58 & 0.51 & 0.34 & 0.36 & 0.072 & 0.27 & 0.07 & 0.44 \\
\hline d89 to 110 & 0.82 & 0.72 & 0.76 & 0.71 & 0.048 & 0.56 & 0.31 & 0.11 \\
\hline d0 to 110 & 0.61 & 0.55 & 0.47 & 0.43 & 0.059 & 0.68 & $<0.01$ & 0.14 \\
\hline
\end{tabular}

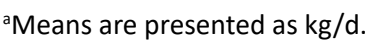

between $\mathrm{T}$-Snip ${ }^{\mathrm{Tx}}$ values and ADG for either endophyte treatment (Figure 1; $\mathrm{P}=0.38$ and 0.48 for pooled- and independent-slope models, respectively, data not shown).

\section{Receiving period}

Cell-mediated and humoral responses: None of the three lymphocyte IFN- $\gamma$ production measurements were affected by either endophyte or exit velocity treatments $(P \geq 0.34$; Table 6$)$. However, a time effect was detected for both response variables across the 4 weeks $(\mathrm{P}<0.01)$ in which the proportion of lymphocytes producing IFN- $\gamma$ increased linearly over time, whereas average lymphocyte production of this cytokine was quadratic during the same time period (Figures 2 and 3, respectively; total IFN- $\gamma$ production by lymphocytes is shown in figure 4). Conversely, Leptospirosis pomona titers were higher for $\mathrm{E}+$ steers, relative to $\mathrm{E}$ - steers, during the receiving period $(\mathrm{P}=0.09$; Table 7). No differences in titer responses were observed between exit velocity designations $(\mathrm{P} \geq 0.44)$.

Performance data: The first 28 days after removal from pasture were analyzed separately to observe potential residual effects of grazing toxic endophyte upon responses to sudden environmental and dietary changes. Effects of endophyte, exit velocity, and their interaction were not significant during the receiving period for ADG (Table $7 ; \mathrm{P} \geq 0.16$ ). However, compared with $\mathrm{E}+$ steers during this period, E- steers consumed approximately $0.37 \mathrm{~kg}^{-1} \cdot \mathrm{hd}^{-1} \cdot \mathrm{d}^{-1}$ more dry matter $(\mathrm{P}=0.03)$, but were less efficient in growth (gain:feed $=0.215 v s$. $0.244 \pm 0.0096$ for $\mathrm{E}$ - and $\mathrm{E}+$, respectively; $\mathrm{P}<0.01$ ). Effects of exit velocity on DMI were also observed during this 4 -week period, as high exit velocity steers had consumed approximately $0.53 \mathrm{~kg}$ ${ }^{1} \cdot \mathrm{hd}^{-1} \cdot \mathrm{d}^{-1}$ less dry matter than low exit velocity steers $(\mathrm{P}<0.01)$ but gain:feed did not differ between the two treatments $(\mathrm{P}=0.94)$. DMI was also normalized for body weight, with high exit velocity steers consuming approximately $0.6 \mathrm{~g} \cdot \mathrm{kg} \mathrm{BW}^{-1} \cdot \mathrm{d}^{-1}$ less dry matter during this $28 \mathrm{~d}$ period, indicating the observed influence of exit velocity on DMI during the early receiving period was partly independent of body weight.

Finishing period: Effects of both endophyte and exit velocity treatments were observed throughout the finishing period. Steers previously grazed on $\mathrm{E}+$ pastures maintained a numerically higher ADG during each weigh interval of the finishing period, resulting in an overall $0.09 \mathrm{~kg} / \mathrm{d}$ greater daily gain for the whole finishing period (Table 7; $\mathrm{P}=0.07$ ). Steers previously grazed on $\mathrm{E}+$ pastures also experienced a 0.008 greater G:F ratio than their E- counterparts (Table 7; $\mathrm{P}<0.01)$, but total dry matter intake and dry matter as a percentage of body weight were not different $(P \geq 0.74)$ between endophyte treatments.
High exit velocity animals consumed approximately $0.41 \mathrm{~kg} \cdot \mathrm{hd}^{-1} \cdot \mathrm{d}^{-1}$ less dry matter than low exit velocity steers for the whole finishing period $(\mathrm{P}=0.06)$. Differences in absolute DMI were largely driven by effects during the $2^{\text {nd }}$ and $3^{\text {rd }}$ weigh intervals, as DMI was approximately 0.37 and $0.63 \mathrm{~kg} \cdot \mathrm{hd}^{-1} \cdot \mathrm{d}^{-1}$, respectively, greater in low exit velocity steers $(\mathrm{P}=0.03)$, although treatment differences were not detected when DMI was examined as a percentage of body weight $(P \geq 0.15)$. Exit velocity also affected whole finishing period gain efficiencies, with high exit velocity animals outperforming low exit velocity steers by approximately $0.007 \mathrm{~kg}$ of body weight gained per kilogram of feed $(\mathrm{P}=0.01)$. However, no differences in ADG $(\mathrm{P}=0.72)$ were observed between exit velocity treatments.

Carcass data: All carcass data are presented in Table 8. Despite the performance differences between treatments during the finishing period, animal carcass measurements were not notably affected by endophyte or exit velocity. Steers previously grazed on E+ pastures maintained higher kidney, pelvic, heart fat percentages $(\mathrm{P}=0.05)$, but did not differ from $\mathrm{E}$ - steers in backfat measurements $(\mathrm{P}=0.20)$ or marbling scores $(\mathrm{P}=0.80)$. Low exit velocity steers had higher yield grades $(\mathrm{P}=0.04)$ but did not differ from high exit velocity steers in other carcass measurements $(P \geq 0.19)$.

\section{Discussion}

\section{Grazing period}

Circulating prolactin concentrations can be utilized as a physiological indicator of exposure to ergot alkaloids, with lower concentrations of prolactin observed following consumption of these toxins [25]. In this study, prolactin concentrations analyzed on $\mathrm{d} 32$ and $\mathrm{d} 110$ of the grazing period corroborated expectations from pasture alkaloid concentration, with steers grazing E+ pastures having lower serum prolactin concentrations.

The data collected during the grazing period agree with most reports of animals grazing tall fescue pastures. Average daily gain for the whole grazing period was approximately $0.13 \mathrm{~kg}$ lower in $\mathrm{E}+$, as compared with E-, steers, which is consistent with reports from others [26-29] and a common sign of fescue toxicosis [30,31].

Fescue toxicosis signs are typically more apparent during periods of increased temperature and humidity [17]. Over the first three weigh intervals, the THI steadily increased to its apex just below the emergency heat stress point (Figure 5), and thus above the alert and danger levels, described by Hahn GL [32]. This was particularly evident during the $3^{\text {rd }}$ interval which coincided with the highest THI values for the entire grazing season, when weight gains in both treatments decreased by 33 to $53 \%$ compared with the $2^{\text {nd }}$ interval. Prior to the start of the $4^{\text {th }}$ weigh interval, the THI decreased to near the alert, or lowest, heat stress level [32], and remained relatively constant through the duration of grazing. During this time, growth rates rebounded to levels similar to those observed for the second interval for both endophyte treatment groups.

\section{Immunological responses}

Humoral immune response, in the form of Leptospirosis pomona antibody production, was impacted by endophyte treatment, with increased production in E+ steers. Despite the consistency of this result with other post-endophyte bovine titer responses [33,34], investigation of a mechanistic explanation has yet to be provided. One possibility is this increased humoral immunity may be driven by serotonergic responses due to consumption of endophytic alkaloids. Serotonin treatment, in the presence of LPS, was reported to stimulate $B$ cell proliferation in rats and mice, with similar effects observed 


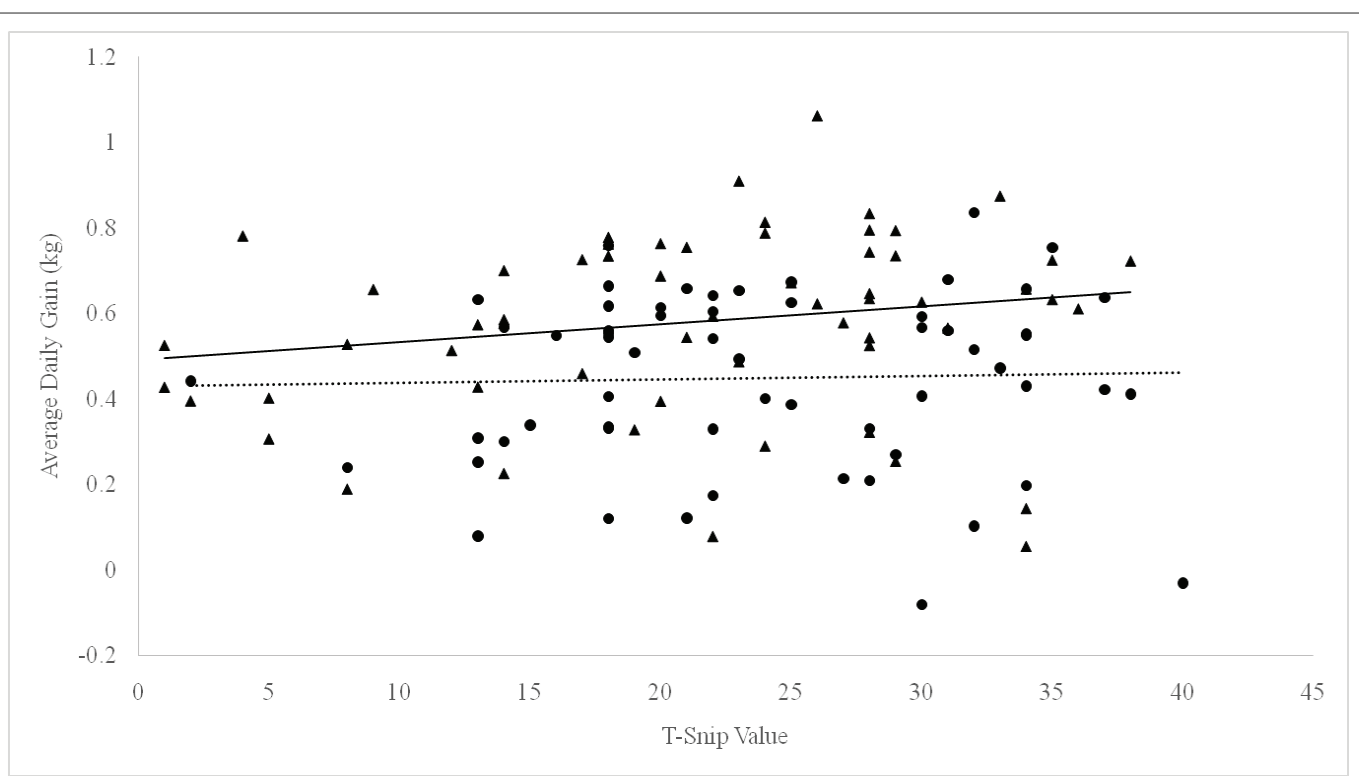

Figure 1: T-snip scores from steers $(n=120)$ grazing toxic $(E+)$ or novel $(E-)$ endophyte tall fescue pastures for $110 \mathrm{~d}$. Scores range from 0 to 50 , with higher values suggested to be associated with greater toxic fescue tolerance. Trend lines, based on endophyte treatments, indicated T-snip scores were not a good determinant for toxic fescue tolerance. The $R^{2}$ for $E-(\boldsymbol{\Delta}$, solid line) steers was 0.0351 , whereas it was 0.0011 for $E+(\bullet$, dashed line) steers, indicating that no correlation between expression of the T-snip gene and average daily gain on pasture existed. Analysis of variance, with inclusion of $T$-snip in the model as a covariate, yielded the following: endophyte $(P<0.01)$, exit velocity $(P=0.16)$, endophyte $x$ exit velocity $(P=0.70)$, T-snip $(P=0.38)$.

Table 6: Influence of toxic $(E+)$ and novel (E-) endophyte tall fescue on steer $(n=20)$ peripheral lymphocyte interferon- $\gamma$ (IFN- $\psi$ ) production during the first $28 \mathrm{~d}$ of the finishing period, with exit velocity (EV) as a covariate.

\begin{tabular}{|l|c|c|c|c|c|c|c|c|}
\hline & Endophyte Treatment & \multicolumn{4}{|c|}{ P-Value } \\
\hline & E- & E+ & SEM & Endo * EV & Endo * Week & Endo & EV & Week \\
\hline Proportion of lymphocytes producing IFN- $\gamma^{\mathrm{a}, \mathrm{b}}$ & 1.83 & 2.00 & 0.125 & 0.25 & 0.54 & 0.34 & 0.42 & $<0.01$ \\
\hline Average lymphocyte production of IFN- $\nu^{\mathrm{a}, \mathrm{c}}$ & 10.31 & 10.39 & 0.087 & 0.74 & 0.59 & 0.82 & 0.67 & $<0.01$ \\
\hline Total lymphocyte population production of IFN- $\gamma^{\mathrm{a}, \mathrm{d}}$ & 12.14 & 12.40 & 0.162 & 0.29 & 0.68 & 0.40 & 0.62 & $<0.01$ \\
\hline
\end{tabular}

\section{${ }^{a}$ Means are presented as natural log-transformed}

${ }^{\mathrm{b}}$ Percent of peripheral blood mononuclear cells expressing interferon- $\gamma$

'Mean fluorescence intensity of peripheral blood mononuclear cells expressing interferon- $\gamma$

dProduct of lymphocyte proportion and average production of interferon- $\gamma$ values

eOnly high exit velocity steers were selected for these analyses. Thus, exit velocity was included as a covariate rather than a treatment effect

using the serotonin agonist 8-OH-DPAT [35]. Ergovaline has been reported to bind with certain serotonin receptor subtypes and induce vasoconstriction in cattle via alteration of serotonin receptors [36,37]. Thus, consumption of this alkaloid by $\mathrm{E}+$ steers may have contributed to the observed increased titer response against Leptospirosis pomona.

It is also possible the increased titer responses in E+ steers were driven by a previous decrease in the plane of nutrition. Pollock JM, et al. [38] reported calves fed a greater amount of milk substitute each day prior to weaning had lower vaccination titers to horse red blood cell (administered post-weaning), indicating a previous lower plane of nutrition may increase vaccine efficacy, even after the nutrient restriction period has ceased. The steers grazing E+ pastures experienced lower ADG than E- steers. Decreased DMI is generally recognized as a primary effect of consumption of endophyte-associated alkaloids $[7,31,39]$, indicating that $\mathrm{E}+$ steers were on a lower plane of nutrition. To determine if the increased humoral responses of cattle previously grazed on $\mathrm{E}+$ pastures is a direct result of alkaloid exposure, lower plane of nutrition, or a combination of the two, future research is needed.

In contrast with humoral immune responses, cell-mediated responses were unaffected by endophyte treatment in this study. This finding, on the surface, conflicts with results from other studies conducted by our lab examining relationships between postendophyte and lymphocyte IFN- $\gamma$ production [40]. However, there are three key differences between the current study and those two experiments. First, this study utilized steers whereas in Altman AW [40], we investigated this relationship in heifers. It is unclear what role sex hormones may play in this relationship, if any. Secondly, total DMI was controlled and equivalent between E- and E+ treatment groups in those experiments, but was not controlled (and likely differed between endophyte treatments, as reflected by ADG) during the grazing period of the current experiment. Third, in our other work, heifers were fed a known concentration of ergovaline + ergovalinine each day, potentially increasing the ability to detect differences 


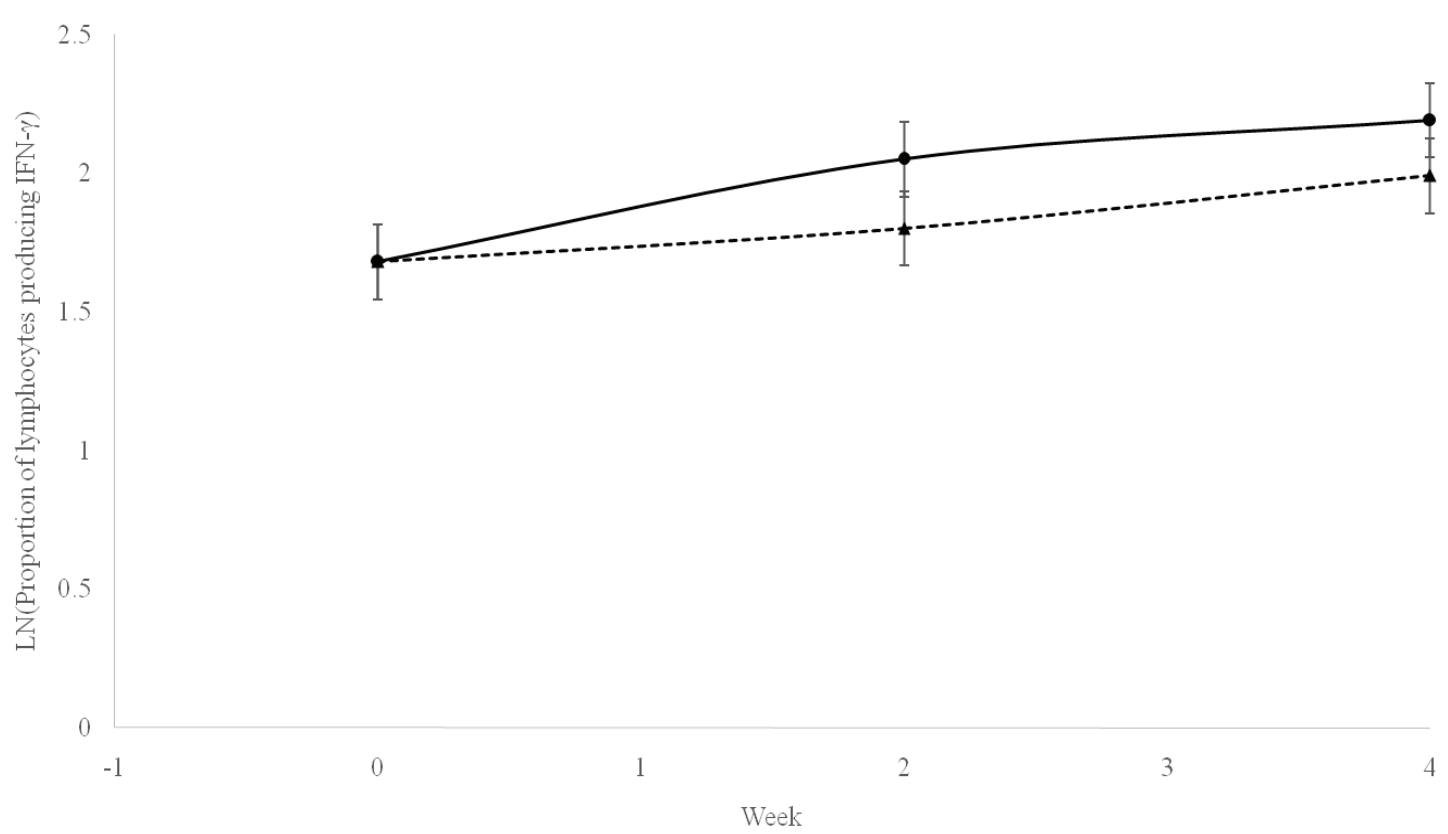

Figure 2: Proportion of lymphocytes expressing interferon- $\gamma$ by week in steers $(n=20)$ previously grazed on toxic $(E+)$ or novel $(E-)$ endophyte tall fescue pastures during receiving phase. Only high exit velocity steers ( $n=1 /$ paddock) were utilized for this analysis. Endophyte treatment did not influence the proportion of lymphocytes expressing interferon- $\gamma(P=0.34)$, but these proportions did fluctuate over the 4-week collection period $(P<0.01)$.An interaction between endophyte treatment and week was not detected $(P=0.54)$. $E+=\bullet$. $E-=\boldsymbol{\Lambda}$

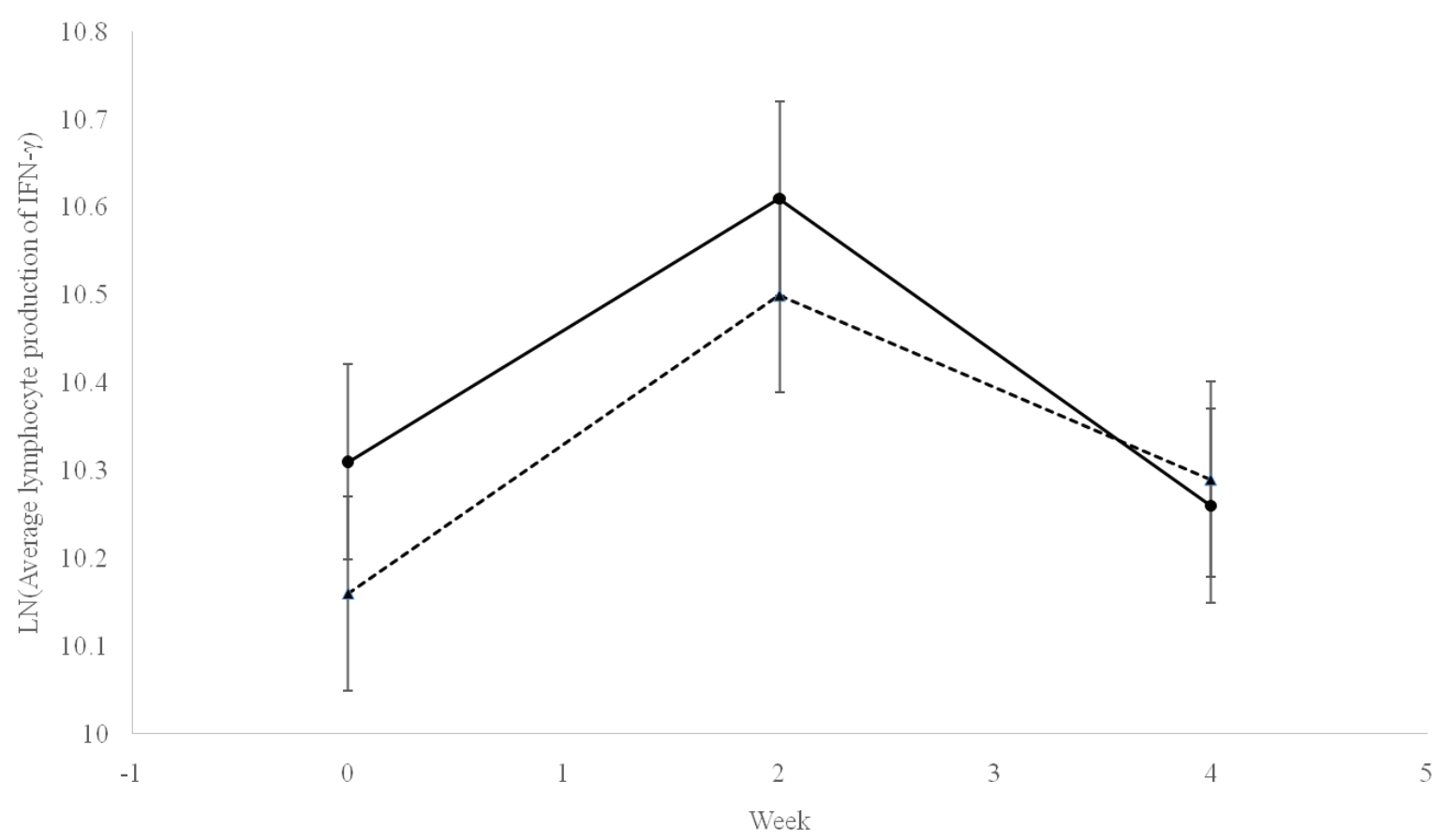

Figure 3: Average lymphocyte production of interferon- $\gamma$ by week in steers $(n=20)$ previously grazed on toxic $(E+)$ or novel $(E-)$ endophyte tall fescue pastures during receiving phase. Endophyte treatment did not influence the average lymphocyte production of interferon- $\gamma(P=0.82)$, but average production of this cytokine by lymphocytes did fluctuate over the 4-week collection period $(P<0.01)$. Only high exit velocity steers

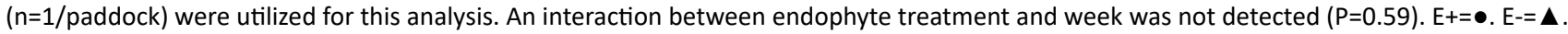




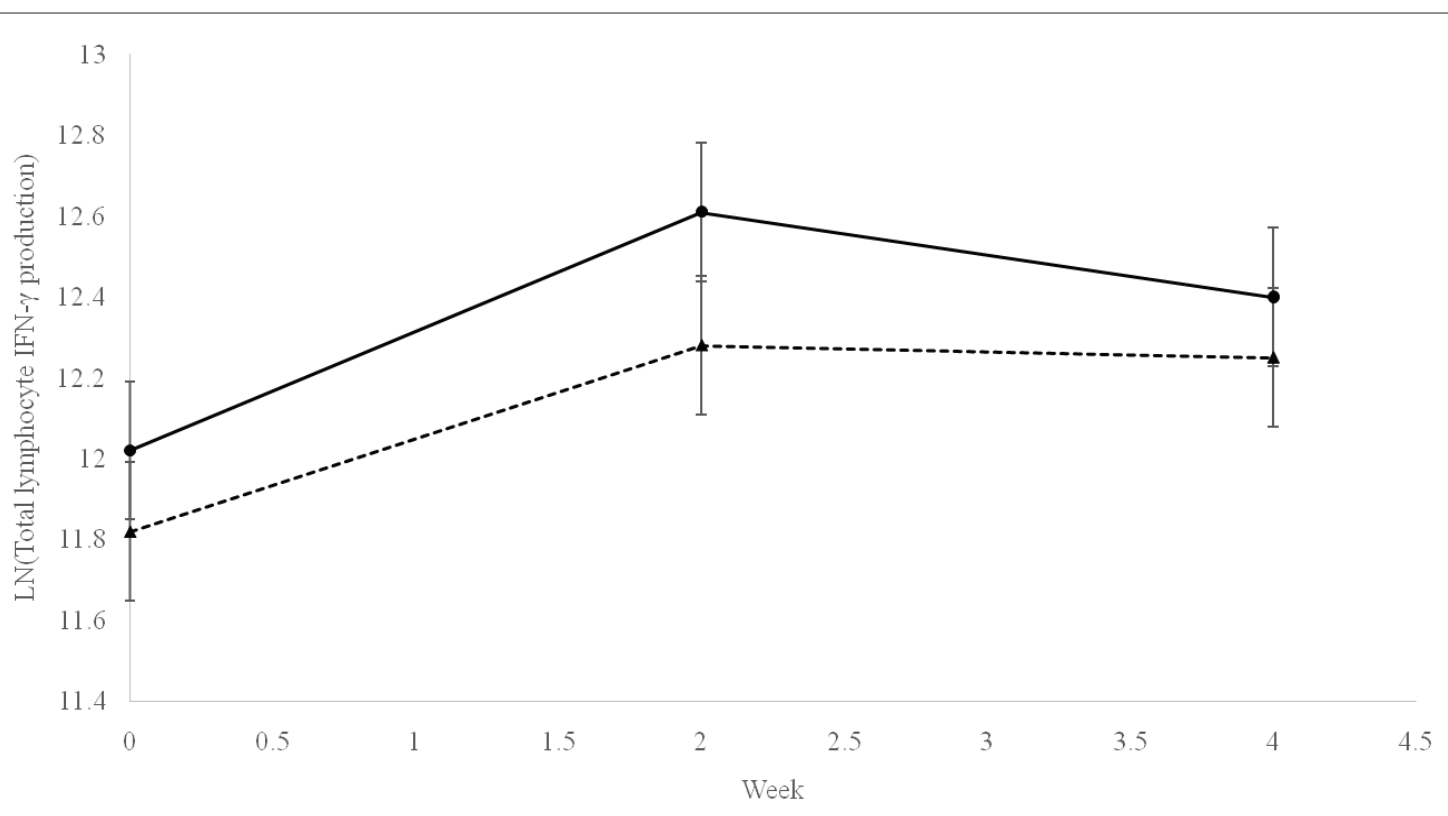

Figure 4: Total lymphocyte interferon- $\gamma($ IFN- - ) production by week in steers $(n=20)$ previously grazed on toxic $(E+)$ or novel $(E-)$ endophyte tall fescue pastures during receiving phase. Total IFN $-\gamma$ production was calculated as the product of the average production of IFN- $\gamma$ and the proportion of lymphocytes producing IFN- $\gamma$. Only high exit velocity steers ( $n=1 /$ paddock) were utilized for this analysis. Endophyte treatment did not influence the total lymphocyte production of IFN- $\gamma(P=0.40)$, but total production of this cytokine by lymphocytes did fluctuate over the 4-week collection period $(P<0.01)$. An interaction between endophyte treatment and week was not detected $(P=0.68)$. $E+=\bullet$. $E-=\boldsymbol{\Lambda}$.

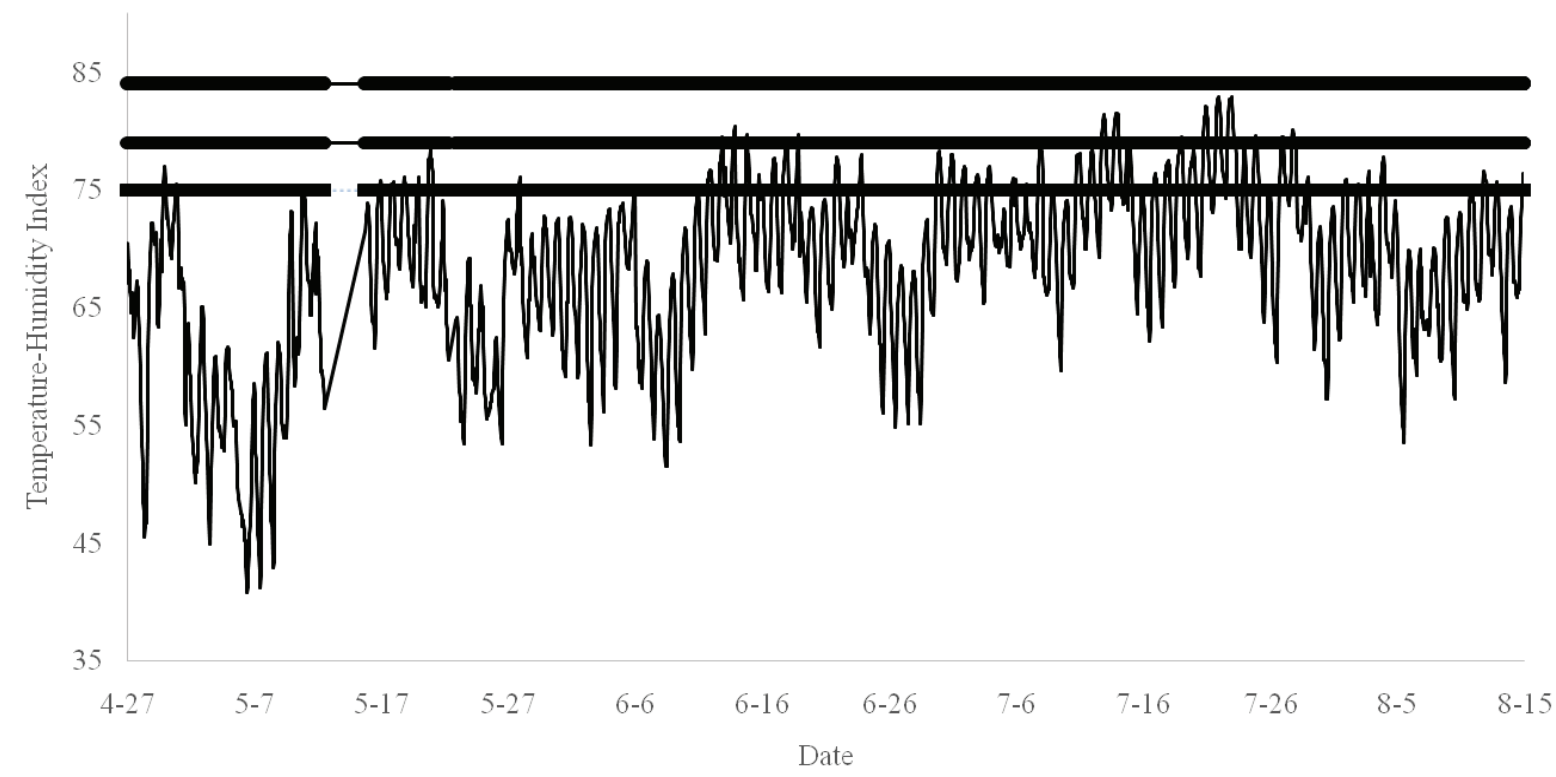

Figure 5: Environmental temperature-humidity index during the $110 \mathrm{~d}$ grazing period. The fluctuating line represents the ambient THI in pastures, which were adjacent to the NOAA weather station used to collect these data. There are missing data due to station malfunction from $5 / 11$ (d15) at 1300 to $5 / 14$ (d18) at 1600 and 5/21 (d25) at 0700 to 5/21 (d25) at 2000. The three straight lines represent the three levels of heat stress described by Hahn, GL [32]: Alert (bottom, THI=75), Danger (middle, THI=79), and Emergency (top, THI=84). 
Table 7: Influence of toxic $(E+)$ and novel $(E-)$ endophyte tall fescue and exit velocity $(E V)$ on steer $(n=118)$ growth performance and humoral immune responses during a $167 \mathrm{~d}$ finishing period following summer grazing.

\begin{tabular}{|c|c|c|c|c|c|c|c|c|}
\hline & \multicolumn{2}{|c|}{ E - } & \multicolumn{2}{|c|}{$E+$} & \multirow[b]{2}{*}{ SEM } & \multicolumn{3}{|c|}{ P-Value } \\
\hline & Low & High & Low & High & & $\begin{array}{c}\text { Endo * } \\
\text { EV }\end{array}$ & Endo & EV \\
\hline \multicolumn{9}{|l|}{ ADG (kg) } \\
\hline d110-138 & 1.86 & 1.66 & 1.89 & 1.86 & 0.109 & 0.40 & 0.27 & 0.24 \\
\hline d138-166 & 1.55 & 1.62 & 1.76 & 1.75 & 0.117 & 0.71 & 0.10 & 0.73 \\
\hline d166-194 & 2.44 & 2.29 & 2.35 & 2.39 & 0.101 & 0.26 & 0.93 & 0.48 \\
\hline d194-235a & 2.05 & 2.25 & 2.14 & 2.23 & 0.107 & 0.42 & 0.61 & 0.02 \\
\hline $\mathrm{d} 235-256^{\mathrm{b}}$ & 1.61 & 1.78 & 1.83 & 1.73 & 0.171 & 0.20 & 0.39 & 0.72 \\
\hline d156-177 & 1.41 & 1.19 & 1.31 & 1.51 & 0.176 & - & - & - \\
\hline do-Finish ${ }^{d}$ & 1.95 & 1.95 & 2.02 & 2.05 & 0.073 & 0.78 & 0.07 & 0.72 \\
\hline \multicolumn{9}{|l|}{ DMI (kg) } \\
\hline d110-138 & 8.52 & 7.82 & 7.98 & 7.70 & 0.207 & 0.18 & 0.04 & $<0.01$ \\
\hline d138 & 11.94 & 11.29 & 12.01 & 11.42 & 0.435 & 0.92 & 0.72 & 0.03 \\
\hline d166-194 & 12.68 & 11.79 & 12.39 & 12.00 & 0.336 & 0.38 & 0.88 & 0.03 \\
\hline d194-235a & 12.79 & 12.38 & 12.55 & 12.59 & 0.326 & 0.39 & 0.96 & 0.50 \\
\hline $\mathrm{d} 235-256^{\mathrm{b}}$ & 11.83 & 11.93 & 11.45 & 11.23 & 0.272 & 0.47 & 0.03 & 0.80 \\
\hline d156-177 & 10.81 & 11.14 & 10.59 & 10.94 & 0.196 & -- & - & - \\
\hline d0-Finish ${ }^{d}$ & 11.66 & 11.07 & 11.42 & 11.18 & 0.267 & 0.41 & 0.74 & 0.06 \\
\hline \multicolumn{9}{|l|}{$\begin{array}{l}\text { DMI (g/kg } \\
\text { BW) }\end{array}$} \\
\hline & & 20.5 & & 20.4 & 0.48 & 0.74 & 0.32 & 0.04 \\
\hline d138-166 & 26.5 & 26.4 & 27.7 & 26.5 & 0.50 & 0.20 & 0.17 & 0.16 \\
\hline d166-194 & 25.0 & 24.5 & 25.2 & 24.6 & 0.47 & 0.87 & 0.68 & 0.15 \\
\hline d194-235a & 21.8 & 22.1 & 22.1 & 22.2 & 0.34 & 0.76 & 0.56 & 0.52 \\
\hline d235-256 & 19.0 & 19.9 & 19.4 & 19.2 & 0.39 & 0.15 & 0.64 & 0.29 \\
\hline $\mathrm{d} 156-177^{c}$ & 17.5 & 17.9 & 17.3 & 17.8 & 0.47 & -- & - & -- \\
\hline do-Finish ${ }^{d}$ & 22.8 & 22.5 & 23.0 & 22.6 & 0.24 & 0.82 & 0.33 & 0.14 \\
\hline \multicolumn{9}{|l|}{$\mathrm{G}: \mathrm{F}$} \\
\hline d110-138 & 0.217 & 0.212 & 0.236 & 0.252 & 0.0096 & 0.29 & $<0.01$ & 0.55 \\
\hline d138-166 & 0.133 & 0.143 & 0.147 & 0.148 & 0.0104 & 0.51 & 0.20 & 0.42 \\
\hline d166-194 & 0.198 & 0.194 & 0.191 & 0.201 & 0.0062 & 0.22 & 0.97 & 0.56 \\
\hline d194-235a & 0.163 & 0.182 & 0.170 & 0.179 & 0.0065 & 0.24 & 0.57 & $<0.01$ \\
\hline d235-256 & 0.136 & 0.150 & 0.160 & 0.148 & 0.0156 & 0.21 & 0.28 & 0.94 \\
\hline d156-177c & 0.130 & 0.107 & 0.124 & 0.149 & 0.0200 & -- & - & -- \\
\hline d0-Finish ${ }^{d}$ & 0.169 & 0.176 & 0.177 & 0.184 & 0.0044 & 0.92 & $<0.01$ & 0.01 \\
\hline $\begin{array}{l}\text { Lepto. } \\
\text { pomona } \mathrm{e}, \mathrm{f}\end{array}$ & 6.65 & 6.47 & 7.02 & 6.86 & 0.270 & 0.96 & 0.09 & 0.44 \\
\hline
\end{tabular}

ancludes all 5 blocks in analyses.

${ }^{b}$ Includes only 2 blocks in analyses.

'Only 1 block included for the means. No statistics available.

${ }^{\mathrm{d} A n a l y s i s}$ of full finishing period for all blocks.

eMeans presented are natural log transformed.

${ }^{\text {fData }}$ were collected during first 28 days of finishing period.

between endophyte treatments. In the present study, average pasture concentrations were obtained at the beginning of the grazing season. However, these concentrations are known to fluctuate throughout the year [41] and the amount of grass consumed, including the total amount of alkaloid ingested each day, was not measured in the current experiment. Therefore, to further investigate the relationship, or lack thereof, between E+ consumption and lymphocyte IFN- $\gamma$ production in steers, future research should be conducted in a manner which better accounts for alkaloid consumption.

\section{Finishing period growth performance}

Effects of endophyte treatment on gain efficiency, DMI, and ADG during the first 28 days of the finishing period indicated steers grazed on toxic endophyte pastures may have been experiencing a compensatory response following the restricted growth observed during the grazing period. The increased absolute dry matter intake by E- steers over the first $28 \mathrm{~d}$ of the finishing period was a result of the relatively larger size of these animals compared with E+ steers during this weigh interval, as there was no difference between endophyte treatments when DMI was analyzed as a percentage of body weight.

Periods of compensation, such as that observed for the E+ steers during the second weigh interval, have been noted to be commonly preceded and accompanied by increased gain efficiency in animals previously under nutrient restriction relative to those who never experienced the restriction [42]. In that study, the compensatory response in both sheep and cattle subsequent to a period of severe nutrient restriction was observed first as an increased gain efficiency and then later with increased DMI. However, it was noted this increased DMI lasted through the duration of the experiment for calves, but not sheep, which the authors attributed to a more severe nutrient restriction (i.e. greater relative weight loss) in the sheep, thereby encouraging a more rapid and efficient response. The authors concluded this indicates that the degree to which compensation occurs in the animal is dependent upon the severity of the restriction experienced. In the current study, which had a much lower degree of restriction than that noted by Ryan WJ, et al. [42], E+ steers experienced improved gain efficiencies during the receiving period (d110 to 138), with a tendency from d138 to 166 to consume a greater amount of dry matter (as a percentage of body weight). This indicated that compensatory mechanisms, although softened in comparison to the aforementioned study, may have been present during the first $56 \mathrm{~d}$ in the feedlot, attributing to the overall difference in ADG observed for the finishing period.

Periods of nutrient restriction have also been associated with decreased liver and gastrointestinal tract weights [43-45]. The restricted growth of these organs, once the nutrient restriction has been alleviated, induces a greater deposition of protein, as opposed to fat, in these animals [43]. Therefore, it is possible the improved growth efficiency of E+, compared with E-, steers during the feedlot period of the present study may have resulted from an increased protein deposition due to decreased liver and gastrointestinal tract sizes arising from the decreased growth of these steers during the grazing period. This mechanism for compensation may assist in further explaining the observed titer responses, which were measured during the same period. Following a period of malnutrition, children supplemented with $175 \mathrm{cal} / \mathrm{kg}$ and $4 \mathrm{~g}$ of protein had greater typhoid immunization responses than was observed prior to supplementation and in a group supplemented with $100 \mathrm{cal} / \mathrm{kg}$ and $1 \mathrm{~g}$ of protein [46]. If compensatory responses were present in E+ steers during the time of vaccination in the current study, as indicated by growth efficiency and daily gain responses, relative nutrient availability could have been increased in these calves, which may have contributed to the increased titer responses.

Finishing period gain efficiency and DMI were also influenced by exit velocity treatment, as animals with greater exit velocities maintained higher growth efficiencies but numerically lower intakes than their low exit velocity herdmates. Despite numerically lower DMI 
Table 8: Influence of toxic $(E+)$ and novel (E-) endophyte tall fescue and exit velocity $(E V)$ on steer $(n=118)$ carcass data.

\begin{tabular}{|c|c|c|c|c|c|c|c|c|}
\hline & \multicolumn{2}{|c|}{$E-$} & \multicolumn{2}{|c|}{$E+$} & \multirow[b]{2}{*}{ SEM } & \multicolumn{3}{|c|}{ P-Value } \\
\hline & Low & High & Low & High & & Endo * EV & Endo & EV \\
\hline Hot Carcass Weight ${ }^{a}$ & 389.8 & 378.2 & 383.7 & 382.0 & 5.03 & 0.34 & 0.82 & 0.19 \\
\hline Yield Grade & 3.24 & 2.99 & 3.24 & 3.10 & 0.100 & 0.55 & 0.54 & 0.04 \\
\hline Ribeye Area ${ }^{b}$ & 87.0 & 87.1 & 86.6 & 89.5 & 1.34 & 0.30 & 0.45 & 0.26 \\
\hline Marbling & 475.0 & 447.2 & 460.6 & 469.1 & 16.69 & 0.23 & 0.80 & 0.52 \\
\hline Backfat ${ }^{c}$ & 1.32 & 1.19 & 1.35 & 1.35 & 0.074 & 0.27 & 0.20 & 0.22 \\
\hline Kidney, Pelvic, Heart Fat ${ }^{d}$ & 1.88 & 1.91 & 1.95 & 1.96 & 0.045 & 0.69 & 0.05 & 0.54 \\
\hline Dressing Percentage $^{d}$ & 62.78 & 62.59 & 62.73 & 62.60 & 0.405 & 0.92 & 0.95 & 0.61 \\
\hline
\end{tabular}

avalues presented in kilograms

${ }^{b}$ Values presented in $\mathrm{cm}^{2}$

'Values presented in $\mathrm{cm}$

'Values presented as \%

(on a \% BW basis) across the finishing period for animals designated as high exit velocity, there was not a corresponding difference in ADG. Although the observed numerical reduction in DMI in the current study is consistent with previous reports $[4,5,47]$, the increase in efficiency differs from others who have reported decreased $[4,5]$ or no difference [48] in gain efficiencies in high, as opposed to low, exit velocity animals. Potential reasons for this difference are unknown. Nonetheless, these results indicate that exit velocity relationships with efficiency of feed conversion are less consistent than relationships with DMI. Much more work needs to be done to begin to develop a mechanistic understanding of the relationships between various measures of temperament and factors that drive animal growth.

\section{Carcass data}

Consumption of E+ pastures has been noted to influence lipid metabolism in cattle, with $\mathrm{E}+$ cattle maintaining lower serum cholesterol concentrations during grazing than calves on E- pastures $[8,33,49]$. In the current study, previous exposure to toxic endophyte pasture had no apparent effect on fat deposition, with the exception of $\mathrm{KPH}$ fat. Differences in KPH due to endophyte treatment have not been noted following a finishing period in other studies [50,51]. Although the endophyte effect was significant, the magnitude of the response (only $3 \%$ greater for E+ compared with E-) is likely of minimal physiological importance.

Conversely, the observed differences in yield grade between exit velocity groups present an intriguing treatment effect. Yield grade is calculated using an equation that incorporates the measured carcass characteristics of backfat, $\mathrm{KPH}$, ribeye area, and hot carcass weight [52]. Despite the appearance of a consistent relationship between exit velocity and yield grade in the present study (i.e. no interaction with endophyte treatment and lower yield grade associated with increased exit velocity), the main driver of this relationship differed between endophyte treatment groups. In E- steers, the change in yield grade was associated with numerically lower backfat whereas in E+ steers, the relationship between exit velocity and calculated yield grade was mathematically primarily related to a numerical change in ribeye area. However, neither of these carcass characteristics were affected by either endophyte nor exit velocity treatments, indicating these differences were very subtle, though distinct enough to affect overall yield grade.

\section{Conclusions}

The results from this study indicate that both toxic endophyte and animal exit velocity may influence growth performance during grazing and finishing. From a finishing perspective, these data indicate that relationships between exit velocity and feed efficiency are more complex than previously envisioned and require further investigation to determine associated mechanisms. Previous toxic endophyte tall fescue consumption improved feedlot growth efficiency and titer response to a bacterial vaccination. The improved growth efficiency was likely the result of compensatory growth resulting from a previous decreased plane of nutrition. However, it is unclear whether the improved titer response was also due to a period of dietary restriction or from a direct effect of an alkaloid upon humoral immunity. Future investigation of the mechanism for this increased responsiveness to vaccination may be useful in formulating and implementing new management strategies to reduce incidence of morbidity among newly received feedlot cattle.

\section{References}

1. Ferguson DM, Johnston D, Burrow HM, Reverter A (2006) Relationships between temperament, feedlot performance and beef quality. Australian Beef-the Leader Conference 161-165.

2. Bruno KA, Vanzant ES, Vanzant KA, Altman AW, Kudupoje M, et al. (2018) Relationship between quantitative measures of temperament and other observed behaviors in growing cattle. Appl Anim Behav Sci 199: 59-66.

3. Altman AW (2015) Impact of Endophyte-Infected Tall Fescue Seed on the Acute Phase and Metabolic Responses of Cattle during an Immunological Challenge. University of Kentucky.

4. Burrow HM, Dillon RD (1997) Relationships between temperament and growth in a feedlot and commercial carcass traits of Bos indicus crossbreds. Aust J Exp Agric 37: 407-411.

5. Petherick JC, Holroyd RG, Doogan VJ, Venus BK (2002) Productivity, carcass and meat quality of lot-fed Bos indicus cross steers grouped according to temperament. Aust J Exp Agric 42: 389-398. 
6. Voisinet BD, Grandin T, Tatum JD, O'Connor SF, Struthers JJ (1997) Feedlot cattle with calm temperaments have higher average daily gains than cattle with excitable temperaments. J Anim Sci 75: 892896.

7. Aldrich CG, Paterson JA, Tate JL, Kerley MS (1993) The effects of endophyte-infected tall fescue consumption on diet utilization and thermal regulation in cattle. J Anim Sci 71: 164-170.

8. Stuedemann JA, Rumsey TS, Bond J, Wilkinson SR, Bush LP, et al. (1985) Association of blood cholesterol with occurrence of fat necrosis in cows and tall fescue summer toxicosis in steers. Am J Vet Res 46: 1990-1995.

9. Cole NA, Stuedemann JA, Thompson FN (2001) Influence of both Endophyte Infestation in Fescue Pastures and Calf Genotype on Subsequent Feedlot Performance of Steers. Prof Anim Scientist 17: 174-182.

10. Duckett SK, Andrae JG, Bouton JH, Hoveland CS, McCann MA (2016) Subsequent feedlot performance and carcass quality of steers that grazed tall fescue with different endophyte types. Crop Forage Turfgrass Manag 2: 1-7.

11. Parish JA, Parish JR, Best TF, Boland HT, Young CA (2013) Effects of selected endophyte and tall fescue cultivar combinations on steer grazing performance, indicators of fescue toxicosis, feedlot performance, and carcass traits. J Anim Sci 91: 342-355.

12. Bruno KA, Vanzant ES, Vanzant KA, McLeod KR (2016) Relationships of a novel objective chute score and exit velocity with growth performance of receiving cattle. J Anim Sci 94: 4819-4831.

13. Phillips TD (2016) 'Lacefield MaxQll' Novel Tall Fescue. University of Kentucky, USA.

14. Sollenberger LE, Vanzant ES (2011) Interrelationships among forage nutritive value and quantity and individual animal performance. Crop Sci 51: 420-432.

15. Yates SG, Powell RG (1988) Analysis of ergopeptine alkaloids in endophyte-infected tall fescue. J Agric Food Chem 36: 337-340.

16. Aiken GE, Strickland JR, Looper ML, Bush LP, Schrick FN (2009) Hemodynamics are altered in the caudal artery of beef heifers fed different ergot alkaloid concentrations. J Anim Sci 87: 2142-2150.

17. Thompson FN, Stuedemann JA (1993) Pathophysiology of fescue toxicosis. Agr Ecosyst Environ 44: 263-281.

18. Ma Y, Meyer KG, Afzal D, Agena EA (1993) Isolation and quantification of ergovaline from Festuca arundinacea (tall fescue) infected with the fungus Acremonium coenophialum by high-performance capillary electrophoresis. J Chromatogr A 652: 535-538.

19. Lane GA, Tapper BA, Davies E (1999) Ergot alkaloids additional to ergovaline in endophyte-infected perennial ryegrass and tall fescue in New Zealand. Ryegrass endophyte: an essential New Zealand symbiosis. Grassland Res Practice Series 7:95-100.

20. Taylor R (1994) The marketing system. In: The marketing system. $2^{\text {nd }}$ Edition, MacMillan Publishing Company, New York, USA.

21. Breathnach CC, Sturgill-Wright T, Stiltner JL, Adams AA, Lunn DP, et al. (2006) Foals are interferon gamma-deficient at birth. Vet Immunol Immunopathol 112: 199-209.

22. Darrah PA, Patel DT, De Luca PM, Lindsay RWB, Davey DF, et al. (2007) Multifunctional TH1 cells define a correlate of vaccinemediated protection against Leishmania major. Nat Med 13: 843.
23. Bernard JK, Chestnut AB, Erickson BH, Kelly FM (1993) Effects of prepartum consumption of endophyte-infested tall fescue on serum prolactin and subsequent milk production of Holstein cows. J Dairy Sci 76: 1928-1933.

24. Bruno KA, Vanzant ES, Altman AW, Kudupoje M, Vanzant KA, et al. (2017) A novel objective chute score interacts with monensin to affect growth of receiving cattle. J Anim Sci 95: 3310-3321.

25. Schillo KK, Leshin LS, Boling JA, Gay N (1988) Effects of EndophyteInfected Fescue on Concentrations of Prolactin in Blood Sera and the Anterior Pituitary and Concentrations of Dopamine and Dopamine Metabolites in Brains of Steers. J Anim Sci 66: 713-718.

26. Parish JA, McCann MA, Watson RH, Paiva NN, Hoveland CS, et al. (2003) Use of non ergot alkaloid-producing endophytes for alleviating tall fescue toxicosis in stocker cattle. J Anim Sci 81: 28562868.

27. Watson RH, McCann MA, Parish JA, Hoveland CS, Thompson FN, et al. (2004) Productivity of cow-calf pairs grazing tall fescue pastures infected with either the wild-type endophyte or a non ergot alkaloidproducing endophyte strain, AR542. J Anim Sci 82: 3388-3393.

28. Tully JK (1992) Influence of endophyte infection of tall fescue with and without white clover on performance, intake, and bite size in steers during the grazing season and subsequent performance in the feedlot. Virginia Tech.

29. Coffey KP, Lomas LW, Moyer JL (1990) Grazing and subsequent feedlot performance by steers that grazed different types of fescue pasture. J Prod Agric 3: 415-420.

30. Waller JC (2009) Endophyte effects on cattle. In: Fribourg HA, Hannaway, D. B., \& West, C. P (eds) Tall fescue for the twenty-first century. Agron Monogr, Madison, WI 289-310.

31. Schmidt SP, Osborn TG (1993) Effects of endophyte-infected tall fescue on animal performance. Agr Ecosyst Environ 44: 233-262.

32. Hahn GL (1999) Dynamic responses of cattle to thermal heat loads. J Anim Sci 77: 10-20.

33. Rice RL, Blodgett DJ, Schurig GG, Swecker WS, Fontenot JP, et al. (1997) Evaluation of humoral immune responses in cattle grazing endophyte-infected or endophyte-free fescue. Vet Immunol Immunopathol 59: 285-291.

34. Dawe DL, Stuedemann JA, Hill NS, Thompson FN (1997) Immunosuppression in cattle with fescue toxicosis. In: Bacon C, Hill $\mathrm{N}$ (eds) Neotyphodium/Grass Interactions. Springer Science and Business Media, New York, NY 411-412.

35. Iken K, Chheng S, Fargin A, Goulet AC, Kouassi E (1995) Serotonin Upregulates Mitogen-Stimulated B Lymphocyte Proliferation through 5-HT1A Receptors. Cell Immunol 163: 1-9.

36. Dyer DC (1993) Evidence that ergovaline acts on serotonin receptors. Life Sci 53: PL223-PL228.

37. Klotz JL, Bush LP, Smith DL, Shafer WD, Smith LL, et al. (2007) Ergovaline-induced vasoconstriction in an isolated bovine lateral saphenous vein bioassay. J Anim Sci 85: 2330-2336.

38. Pollock JM, Rowan TG, Dixon JB, Carter SD (1994) Level of nutrition and age at weaning: effects on humoral immunity in young calves. Brit J Nutr 71: 239-248

39. Hoveland CS, Schmidt SP, King CC, Odom JW, Clark EM, et al. (1983) Steer Performance and Association of Acremonium coenophialum Fungal Endophyte on Tall Fescue Pasture. Agron J 75: 821-824. 
40. Altman AW (2019) Relationships between animal temperament and systemic immune responses in beef cattle exposed to conditions associated with conventional management. University of Kentucky, USA.

41. Rogers WM, Roberts CA, Andrae JG, Davis DK, Rottinghaus GE, et al. (2011) Seasonal fluctuation of ergovaline and total ergot alkaloid concentrations in tall fescue regrowth. Crop Sci 51: 1291-1296.

42. Ryan WJ, Williams IH, Moir RJ (1993) Compensatory growth in sheep and cattle. 1. Growth pattern and feed intake. Aust J Agric Res 44 1609-1621.

43. Carstens GE, Johnson DE, Ellenberger MA, Tatum JD (1991) Physical and chemical components of the empty body during compensatory growth in beef steers. J Anim Sci 69: 3251-3264.

44. Johnson CL, Johnson DE, Rumpler WV (1987) Source and level of alimentation effects on visceral organ mass of fat steers. In: Moe PW, Tyrrell HF, Reynolds PJ (eds) Energy metabolism of farm animals. Rowman and Littlefield, Lanham, MA 50-53.

45. Murray DM, Tulloh NM, Winter WH (1977) The effect of three different growth rates on some offal components of cattle. J Agric Sci Technol 89: 119-128.

46. Suskind R, Sirishinha S, Vithayasai V, Edelman R, Damrongsak D, et al. (1976) Immunoglobulins and antibody response in children with protein-calorie malnutrition. Am J Clin Nutr 29: 836-841.
47. Cafe LM, Robinson DL, Ferguson DM, McIntyre BL, Geesink GH, et al. (2011) Cattle temperament: persistence of assessments and associations with productivity, efficiency, carcass and meat quality traits. J Anim Sci 89: 1452-1465.

48. Francisco CL, Cooke RF, Marques RS, Mills RR, Bohnert DW (2012) Effects of temperament and acclimation to handling on feedlot performance of Bos taurus feeder cattle originated from a rangelandbased cow-calf system. J Anim Sci 90: 5067-5077.

49. Bond J, Powell JB, Undersander DJ, Moe PW, Tyrrell HF, et al. (1984) Forage composition and growth and physiological characteristics of cattle grazing several varieties of tall fescue during summer conditions. J Anim Sci 59: 584-593.

50. Realini CE, Duckett SK, Hill NS, Hoveland CS, Lyon BG, et al. (2005) Effect of endophyte type on carcass traits, meat quality, and fatty acid composition of beef cattle grazing tall fescue. J Anim Sci 83 : 430-439.

51. Duckett SK, Bondurant JA, Andrae JG, Carter J, Pringle TD, et al. (2001) Effect of grazing tall fescue endophyte types on subsequent feedlot performance and carcass quality. J Anim Sci 79: 221.

52. USDA (1997) Official United States standards for grades of carcass beef. Washington, DC. 